\title{
How to Transmit Disaster Information Effectively: A Linguistic Perspective on Japan's Tsunami Warnings and Evacuation Instructions
}

\author{
Kyoko Arai* \\ Faculty of Business Administration, Toyo University, Tokyo 112-8606, Japan
}

\begin{abstract}
When the disastrous tsunamis hit East Japan on 11 March 2011, the hi-tech information transmission system that is the pride of Japan was unable to send out the Tsunami Warnings effectively; many lives were lost as a result. Subsequently, the Japan Meteorological Agency (JMA) set up a committee of experts to improve the overall system. Last year as a result of their meetings, a report on The Improvement of the Information Text for the Tsunami Warnings was announced. The changes are, however, problematic from the linguistics perspective as the committee did not include any experts in the field. This study examines a range of recordings of the Tsunami Warnings and the Evacuation Instructions ${ }^{i}$ given for the East Japan tsunami disaster from the perspective of linguistics, especially pragmatics, whose main objective is to discover how recipients interpret verbal messages. The aim of this article is to propose further improvement to the transmission system of Tsunami Warnings and Evacuation Instructions. This study also emphasizes the necessity and importance of reexamining the overall disaster information transmission issue in Japan, from the linguistics perspective.
\end{abstract}

Keywords communication effectiveness, disaster information, Evacuation Instructions, Japan, Tsunami Warnings

\section{Introduction}

On 11 March 2011, a gigantic M9.0 earthquake occurred in East Japan and was followed by the most disastrous tsunami in recent years. Around 20,000 people were killed or are still missing and 90 percent of the deaths were reported to be the result of drowning.

The Japan Meteorological Agency (JMA) has been criticized for underestimating the force of the tsunami and its information transmission for delaying people's evacuation. To respond to these criticisms the JMA organized a committee, consisting of representatives of municipalities in the Tohoku area, seismologists, and people from the mass media. This group held several meetings to discuss how to convey Tsunami Warnings and Advice more effectively. In the light of the

\footnotetext{
*E-mail: arai-k@toyo.jp
}

surveys conducted of the meetings in the disaster-stricken area and the reports of the meetings (JMA 2011), many people have pointed out that one of the problems was the words and phrases used in the warnings. After three meetings, the JMA decided to make modifications to some of the wording of the Tsunami Warnings and reported them in The Improvement of the Information Text for the Tsunami Warnings $\mathrm{s}^{\mathrm{ii}}$ in 2012.

According to the report, the committee realized that emergency communication should be considered from the standpoint of its audience. But the meetings included no scholar from the field of pragmatics, a specialty subject whose objective is to reveal how the addressees interpret oral communications; nor did they include experts from any other field of linguistics. As a result the modifications are not effective enough from the perspective of linguistics. One of the changes proposed in the report is that the estimated height of a tsunami should be expressed by adjectives if it is over three meters in height, in words such as "huge" and "high." These choices are problematic, because the ambiguity of the adjectives might cause further confusion for the addressees.

The aim of this article is to examine the present disaster information transmission system in Japan, especially focusing on the Tsunami Warnings issued by the JMA and the Evacuation Instructions issued by municipalities from a

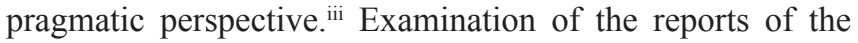
JMA and the Fire and Disaster Management Agency (FDMA), legal documents, and live recordings (YouTube) of outside speakers when the great tsunamis attacked the Tohoku area should clarify the problems of disaster information transmission and indicate some proposed improvements for the whole transmission system. This article also suggests that pragmatics can be a useful framework for constructing the literacy of disaster prevention communication.

\section{The Significance of a Pragmatic Framework}

Pragmatics is a subfield of linguistics. Its aim is to clarify the ways in which context contributes to meaning and to reveal how recipients respond to verbally transmitted information. 
On the one hand, semantics examines meaning that is coded in a given language; on the other hand, pragmatics studies meaning that is inferred by an addressee, according to the context, when listening to a message. Contexts can be supplied by knowledge (memories), sensory perceptions, and the addressee's inferences. Pragmatics explains how people can fill the gap between the decoded meaning and the intended meaning of the speaker. For example, when someone says: "I have to do my homework," they can convey the meaning "I have to go home now." To fill the gap between these meanings, people use their inference ability.

Looking at disaster information transmission from the standpoint of addressees is very important. Arai (2011, 2013a, 2013b) suggested the importance of the addressees' viewpoint and applied the framework of pragmatics to disaster information transmission. Although an addresser tries to convey the necessity of evacuation by saying "Evacuation is necessary when the Evacuation Advice is issued," some addressees might think "Until the Evacuation Advice is issued I can stay home." Kanai and Katada (2011) and Yamori (2009) pointed out that meta-message problems caused a delay in local residents' evacuation. A meta-message is almost always inferred by the addressees, depending on their context. Let us consider the message about an expected tsunami arrival in (1) and the possible meanings inferred in (2) and (3):

(1) "A three-meter tsunami will arrive at Ishinomaki Bay in a few minutes."

(2) (A person who is fishing at Ishinomaki Bay might infer) "Evacuate the bay immediately."

(3) (A person who is working on the fifth floor of a strong building might infer) "Stay there till the Tsunami Warning is called off."

(2) and (3) are concluded as a result of the addressee's reasoning process, which uses each context as the premise. When we study disaster information transmission, how these messages are understood is essential. If we assume that addressees tend to infer multiple meanings from one message depending on the context, as pragmatics does, we will be able to transmit messages more effectively.

\section{Japan's Tsunami Warnings and Evacuation Instructions}

Pragmatics sees communication as a transmission of intentions. When the intention of the addresser is fulfilled, the communication has succeeded. Let us begin by looking at how the intention of the Tsunami Warnings and Evacuation Instructions in Japan may or may not reach local residents by language.

\subsection{Legally Restricted Information Transmission System}

In Japan to avoid information confusion there are legally restricted information routes for Tsunami Warnings and the

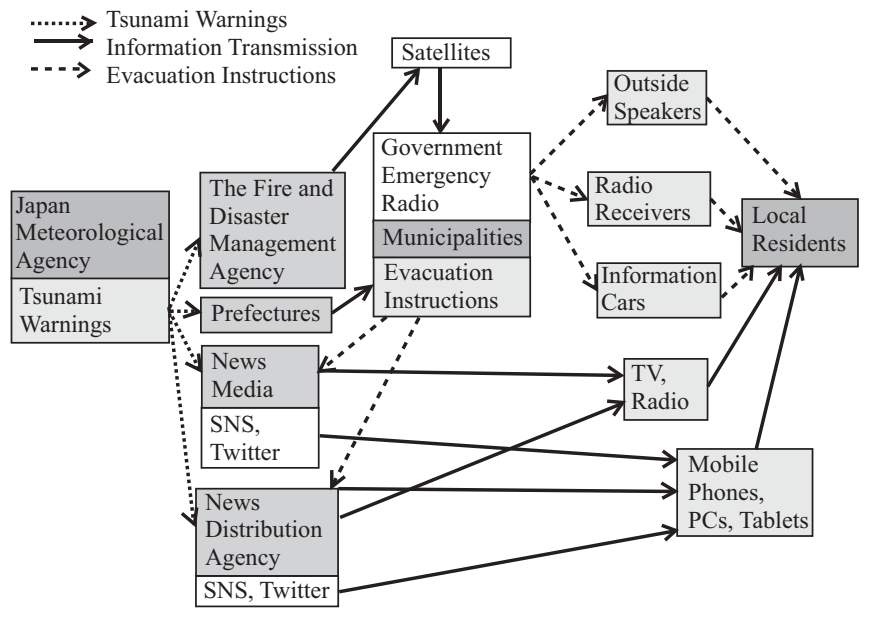

Figure 1. The Tsunami Warnings and the Evacuation Instructions

Note: SNS is Social Network Services, such as Facebook, mixi, and so on.

Evacuation Instructions. The hi-tech information transmission system and routes that are the pride of Japan are shown in Figure 1.

When tsunamis are expected to occur, Tsunami Warnings are issued by the Japan Meteorological Agency (JMA), which is regulated by the Weather (Meteorological) Service Law. ${ }^{\text {iv }}$ The Tsunami Warnings should be issued only by the JMA. This information is transmitted immediately to the municipalities through the Fire and Disaster Management Agency or the prefectures and also to the local residents who should also be alerted to the impending tsunami by the news media. By giving the authority to JMA the source can be limited and the credibility and reliability of the information can be maintained.

On the other hand, the Basic Act on Disaster Control Measures $^{v}$ prescribes that only municipalities can issue the Evacuation Instructions (or Advice) through the agency of a city, town, or village. According to these laws, the JMA and each municipality can issue warnings and instructions, and other institutions and news media can only pass them on to the people (including local residents). Figure 1 shows how the Tsunami Warnings are transmitted to other institutions and how the Evacuation Instructions are transmitted to local residents.

\subsection{The Announcements}

This legal system can be observed in the expressions used in the announcements. (1) is the content example of the Tsunami Warning that is announced by the JMA, and (2) is the Evacuation Instruction expression supposed to be used by municipalities. The actual utterance of a TV news reader (3) informs the viewer about the Tsunami Warnings.

(1) Examples of JMA's Tsunami Information Transmission (effective from 07 March 2013. http://www.seisvol.kishou. go.jp/eq/tsunami_keihou_kaizen/index.html) 
○タイトル 津波情報

Tsunami Information

津波到達予想時刻・予想される津波の高さに関する情 報

Information about the estimated time and height of the first wave

平成23年3月11日14時50分気象庁発表

Issued by the JMA at 14:50, 11 March 2011

○津波到達予想時刻・予想される津波の高さ

Estimated Time and Height of the First Wave

予報区名

第1波の到達予想時刻予想され る津波の最大波の高さ

Districts The estimated time and height of the first big wave

$<大$ 津波警報 $>$ Great Tsunami Warning

\$岩手県 津波到達中推測

巨大

Iwate Prefecture

Tsunami is arriving

Huge

$\$$ 宮城県

11日15時00分

Miyagi Prefecture

11 March, 15:00

巨大

\$福島県

11日15時10分

Huge

Fukushima Prefecture

11 March, 15:00

巨大

Huge

\section{○警戒等の呼びかけ}

Calls for Caution

警報が発表された沿岸部や川沿いにいる人はただちに 高台や避難ビルなど安全な場所へ避難してください。

The people near the coast or river for which the Tsunami Warnings were announced should (please) evacuate and go up a hill or to the evacuation building.

到達予想時刻は、予報区のなかで最も早く津波が到達 する時刻です。場所によっては、この時刻よりもかな り遅れて津波が襲ってくることがあります。

The estimated arrival time is the time the first wave arrives in the district.

The time of the tsunami attack might differ in parts of the same district.

到達予想時刻から津波が最も高くなるまでに数時間以 上かかることがありますので、観測された津波の高さ にかかわらず、警報が解除されるまで安全な場所から 離れないでください。

Between the estimated arrival time of the first wave and the arrival time of the highest wave, a few hours might elapse. Despite the observed tsunami height, (please) stay in a safe place until the tsunami warning is withdrawn.

(2) The Guidelines of the Evacuation Advisory Issuance for Municipalities in Case of Flooding (Cabinet Office, Government of Japan)

＜避難勧告の伝達文（住民あて）の例＞

Evacuation Advisory Expression Examples

こちらは、○○市 (町村) です。ただ今、○時 $○$ 分に ○○地区に対して避難勧告を出しました。

This is ( ) City. We issue Evacuation Advice to ( ) district as of now.
直ちに○○公民館へ避難してください。なお、浸水によ り、○○道は通行できません。（そのほか、 「昨夜からの大雨により、○○時間後には○○川の水位 が危険水位に達するおそれがあります」、「できるだけ 近所の方にも声をかけて避難してください」等）。

Evacuate (the area) to the Community Center immediately.

( ) avenue/street is closed owing to flooding.

Owing to the continuous rain since yesterday there are fears that the water level of ( ) river will reach the danger mark.

When you evacuate tell your neighbors to do so as much as you can.

＜避難指示の伝達文（住民あて）の例＞

Sample Expressions in the Evacuation Instruction to Residents

$\bigcirc \bigcirc$ 市（町村）長の○○です。ただ今、○時○分に ○地区に対して避難指示を出しました。（堤防が決 壊して/○○川が危険水位を突破して）大变危険な状 況です。

This is Mayor ( ) of ( ) City. I have issued the evacuation instruction to ( ) district.

The bank has burst and the water level of the ( ) river exceeds the danger level. This is a state of emergency.

避難中の方は直ちに○○公民館への避難を完了してく ださい。十分な時間がない方は近くの安全な建物に避 難してください。なお、浸水により、○○道は通行で きません。

People who are still evacuating should complete evacuation to the ( ) community center immediately.

( ) avenue/street is now closed owing to flooding.

(3) Nihon Broadcasting Company's Live Program, NNN News, on 11 March 2011 (showing images of Miyako City, Iwate Prefecture) (Source: http://www.youtube.com/ watch?v=ThkQvKLMR3M)

気象庁は先ほど、太平洋岸の青森付近から関東付近ま でを大津波警報、津波警報を北海道の太平洋沿岸から 小笠原諸島、西日本加ら沖縄地方にかけても津波注意 報を発令しています。

The JMA has announced a Big Tsunami Warning to the Pacific coasts from Aomori area to Kanto area, the Tsunami Warning for the Pacific coast of Hokkaido and Ogasawara Islands, the Tsunami Advice for West Japan to Okinawa area.

津波に対する注意を抎えいたします。海の近くにい る人は直ちに避難して下さい。海から離れた高台や頑 丈で高い鉄筋のビルなどに逃げてください。津波は新 幹線以上の速さで襲ってくることもあります。もうす でに丘の方にあがって来ているところもありますの で、くれぐれもご注意ください。

I would like to inform you of the precautions to be taken in the event of tsunami attacks. Those near the ocean should (please) escape immediately. Run up a hill or a 
strong and tall ferro-concrete building far from the ocean. The speed of tsunami attack could be faster than a bullet train. In some places tsunamis have risen above hills. Please be careful.

In (1) the JMA clearly states that it has announced the Tsunami Warnings. The Guidelines of the Evacuation Advisory Issuance for Municipalities in Case of Flooding by the Cabinet Office of the Government of Japan in (2) instructs the municipalities to use such expressions as "We have issued the evacuation instruction to ( ) district" and "We are issuing Evacuation Advice to ( ) district right now." These two examples tell us who should issue the advice and what kind of warnings they issue.

On the other hand, the example of the newsreaders' live announcements and use of such expressions as "The JMA has announced a Big Tsunami Warning. .." and "I would like to inform you of the precautions to be taken in the event of tsunami attacks" clearly state their responsibility is to inform their audience of the Tsunami Warnings, and the advice that they have sent to the news media.

These expressions follow the legal requirements on the disaster information transmission system in Japan. These requirements can control the authority of the information sources and keep the information reliable. From another perspective pragmatics supposes that saying something means conveying an intention. Therefore, the intention each institution has regarding the information transmission can be sketched as in Figure 2.

One way to convey the intention of each institution is to use formally appropriate sentences. In other words, the coherence between an intention and the formal characteristics of the statements used is one of the important issues in disaster information transmission, because the local residents need to judge which information is of most relevance to them. Instructions issued by the mayor are more dependable than information from the JMA, because the mayor is supposed to make decisions on whether to issue the Evacuation Instruction or Advice about whether residents should evacuate by considering the city's geographical characteristics, disaster history, and the city's own hazard map. For instance, when the mayor says, as in (2), "This is Mayor Tanaka. . . I have issued the Evacuation Instruction. .." the addressees can understand that he wants them to evacuate immediately. If the announcement is "The Evacuation Instruction has been issued," the addressees cannot tell who has issued it, so they might think that it is permissible to ignore it.

\section{The Present Problems}

Although there are relevant legal requirements in Japan, in reality the functional information system did not seem to work out in an ideal way.

\subsection{Routes of Information Transmission}

Critics maintain that the hi-tech information transmission system was unable to send out the Tsunami Warnings effectively and many lives were lost as a result. Figure 3 shows information transmission from the viewpoint of local residents.

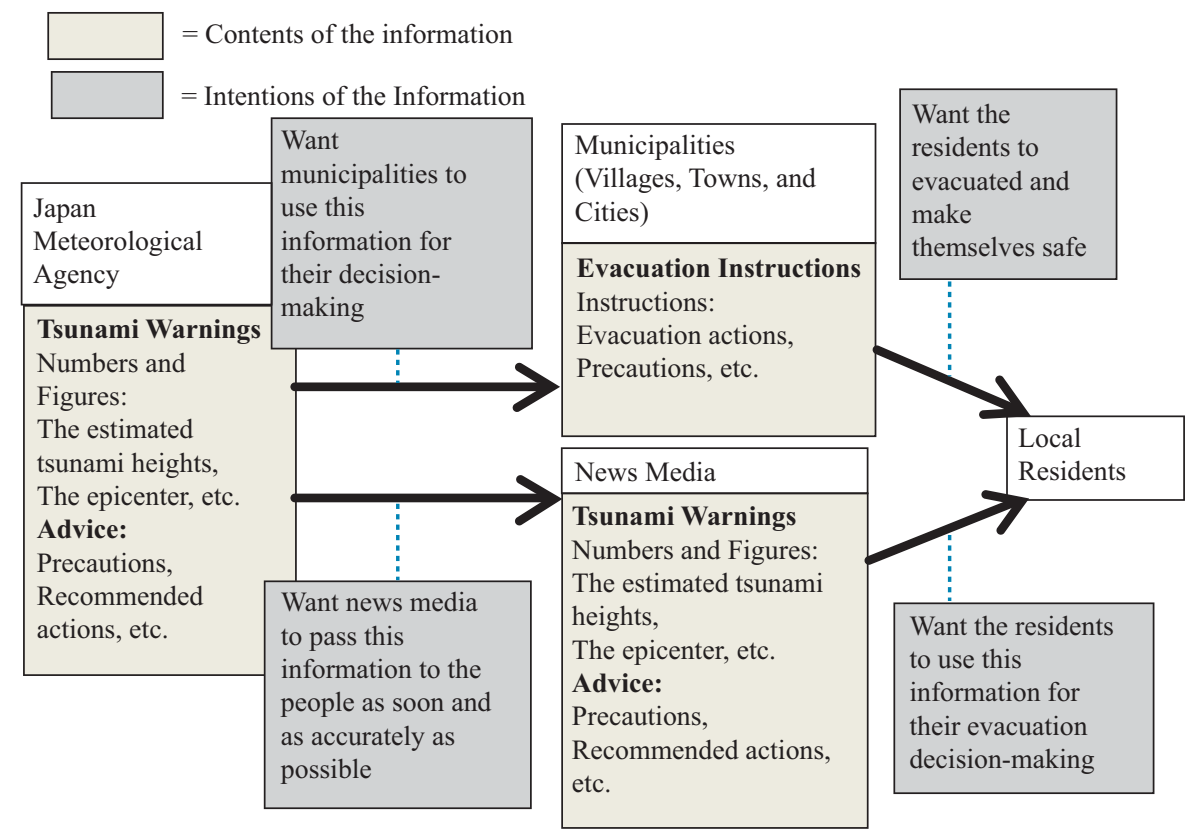

Figure 2. The content and intention of the Tsunami Warnings, multi-media information, and the Evacuation Instructions 
The Contents of Information

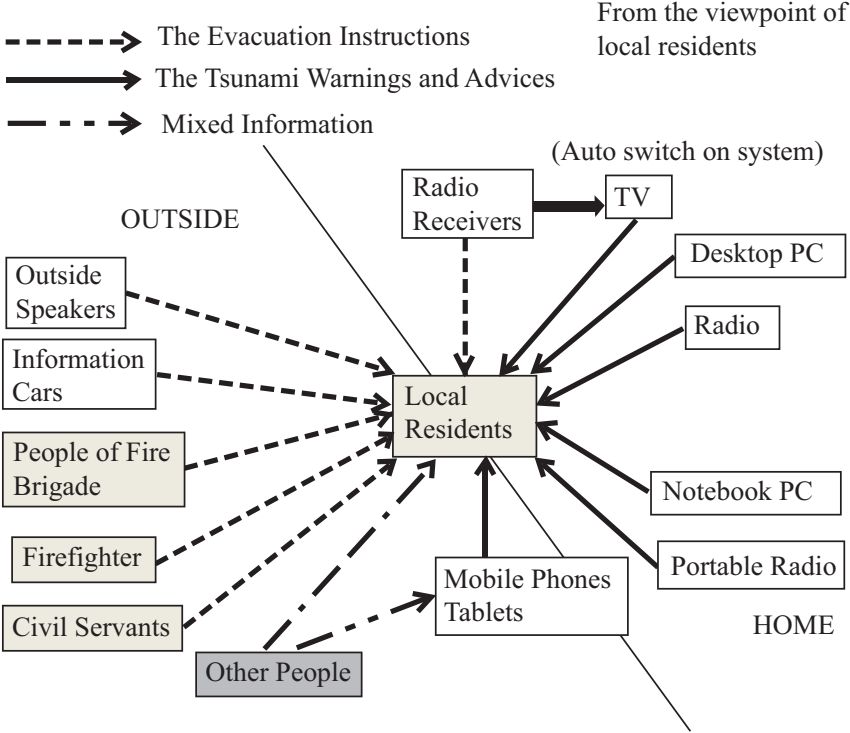

Figure 3. Disaster information transmission from the viewpoint of local residents

One problem that may occur is due to the multiple sources of warning information. Local residents receive information from a number of different media, so they could easily be confused by the Tsunami Warnings and the Evacuation Instructions. In addition, unreliable information reaches local residents via Twitter and SNS (simple notification service) through PCs, cell phones, and tablets. Information is also sent through many different media, and many residents who answered the JMA's survey said, "They are sent to the people over a broad area and we didn't know whom the warnings were meant for. So after a while we stopped paying attention to them."

To solve this problem the relationship between intention and language expressions should be consistent, so the addressees can identify who has issued the announcements. On the other hand, the addressees need knowledge of the whole disaster information system. In particular, they need to know the intention of each announcement (as shown in Figure 2) to decide which piece of information is reliable.

The opposite of the problem discussed above occurs when there are too few means of information transmission. According to a survey conducted in November and December 2011 by the municipality of Kamaishi, one of the tsunami disaster areas in Iwate prefecture, ${ }^{\mathrm{vi}} 30$ percent of the local residents could not get any information about the Tsunami Warnings, and the final biggest tsunami (estimated over 10 meters) warning was recognized by only 3.3 percent of the people. The rest of the local residents knew that the Tsunami Warning had been issued, but they were not sure about the estimated arrival time and height of the tsunami and thus tended to underestimate the threat the tsunami represented. This problem happened because the electricity supply was cut after the great earthquake. When the electricity supply is cut, the resulting situation is as simulated in Figure 4.

There were many people who could not see the images of the tsunamis impacting many of East Japan's coastal areas, which were broadcast all over the world, until a few weeks later when the electricity supply was restored. The terrible images might have persuaded many people to evacuate the disaster area before they did.

In this situation the Tsunami Warnings, including precautions and advice, reach local residents only by radio, although unreliable and contradictory information can still reach them via cell phones and tablets. This reduces information reliability. Electricity is most likely to be cut when a big earthquake hit, so the possibility of the situation in Figure 4 occurring is very high. In addition, cell phones and tablets are always cut a few minutes after a disaster happens in order to reduce heavy traffic and to keep the public service lines alive. Therefore, in this situation, the voices of outside speakers, information cars, and officials (fire brigade, firefighters, and civil servants) operating play a very important role in the evacuation of local residents.

Therefore, the fundamental problem was that most of the local residents could not hear the biggest tsunami warning in Kamaishi City, and many other heavily impacted disaster areas might have experienced a similar insufficient transmission of those warning voices.

\subsection{Expressions Used in the Evacuation Instructions}

As shown in Figure 2 and in Section 3, each institution has its own intention in terms of transmitting information and messages. At the very end of the chain, the Evacuation Instructions are sent to the local residents by outside speakers, information cars, and people (fire brigade, firefighters, and civil servants). Below are the announcements that were

The Contents of Information

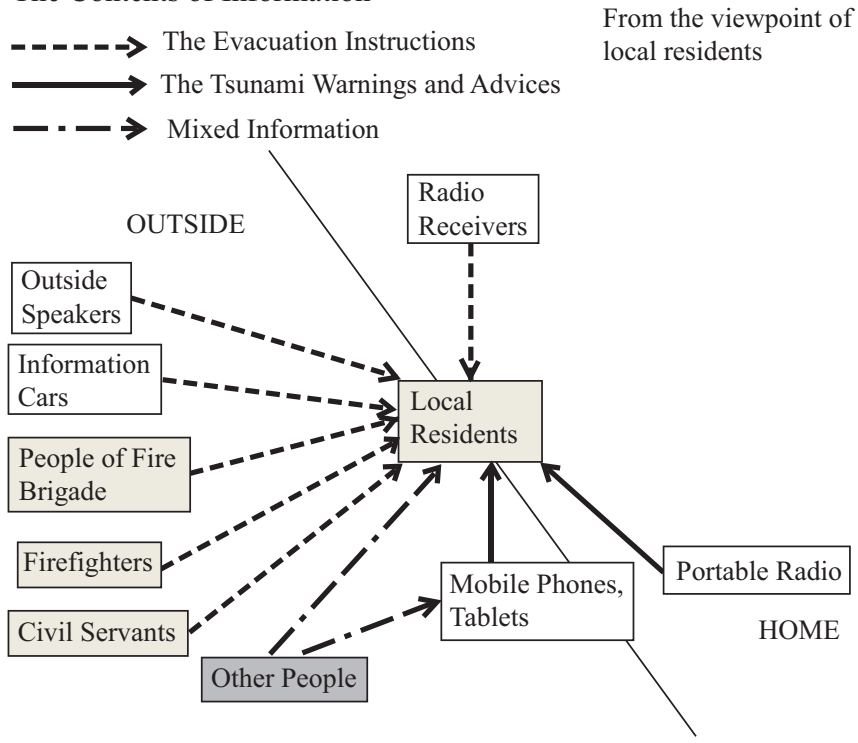

Figure 4. Information transmission from the standpoint of the addressees when electricity is cut 
transcribed from YouTube recordings ${ }^{\text {vii }}$ at the time when the tsunamis struck the coast in the Tohoku area on 11 March 2011. They were all recorded by people in the disaster area at the moment of the attacks.

Up to now we have looked at what the addressers sent, but this is what the addressees heard.

(4) The Announcements of Outside Speakers through Disaster Government Radio

a. Shiogama Bay, Miyagi Prefecture (male, recorded voice, slowly)

...〜メーター、〜メーター ...meters, ...meters, 水位が上がっています。

The level of water is rising.

ただちに高台に避難して下さい。

(Please) evacuate to a hill immediately.

（サイレン？） (siren?)

b. Oofunato Bay, Iwate Prefecture (male, recorded voice, slowly)

大津波警報が発表されています。

The Big Tsunami Warning has been issued (is effective).

c. Aomori Prefecture (male, recorded voice, slowly) 直ちに指定避難所、または高台へ避難して下さい。 (Please) evacuate to the designated emergency site or a hill.

d. Miyako City Hall, Iwate Prefecture (male, recorded voice, slowly)

チャイム $\cdots$ (chime)

高台に避難して下さい。Please evacuate to a hill.

大津波警報が...The Big Tsunami Warning is ...

チャイム (chime)

e. Oofunato Bay, Iwate Prefecture (male, natural voice, slowly)

チャイム (chime)

お知らせします。

May I have your attention, please.

津波警報第3号、津波警報第 3 号、現在、津波警報発 令中です。

Tsunami Warning Number 3, Tsunami Warning Number 3, the Tsunami Warning has been issued (is effective).

沿岸住民は直ちに高台に避難して下さい。

People at the coast, (please) evacuate to a hill immediately.

現在、津波警報発令中です。

The Tsunami Warning has been issued (is effective).

沿岸住民は直ちに高台に避難して下さい。

People at the coast, (please) evacuate to a hill immediately.

こちらは防災大船渡広報です。

This is the Disaster Prevention Oofunato Publicity Department. f. Toutan, Oshirohama Bay(male, natural voice? fast)

サイレン、サイレン (sirens)

ただ今、岩手県沿岸に大津波警報が発表されまし

た。

The Big Tsunami Warning has been announced for the coast of Iwate Prefecture.

高いところで $3 \mathrm{~m}$ 以上の津波が予想されます。

A tsunami of more than three meters is expected.

沿岸付近にいる方は、直ちに近くの高台か避難場所 に避難するよう指示します。

People near the coast we (I) instruct you to escape to a hill or an emergency evacuation site immediately.

ただ今、岩手県沿岸に大津波警報が発表されており ます。

Now the Big Tsunami Warning has been announced (is effective) for the coast of Iwate Prefecture.

高いところで $3 \mathrm{~m}$ 以上の津波が予想されます。

A tsunami of more than three meters is expected.

沿岸付近にいる方は、直ちに近くの高台か避難場所 に避難するょう指示します。

People near the coast, we (I) instruct you to escape to a hill or an emergency evacuation site immediately.

g. Onagawa Tow, Miyagi Prefecture (female, natural voice, slowly)

(チャイム) (chime)

役場特別警戒本部よりお知らせいたします。

This is the information from the Town Office Emergency Headquarters.

現在、宮城県沿岸部に大津波警報が発令されており ます。

The Big Tsunami Warning has been issued (is effective) for the coast of Iwate Prefecture.

午後 3 時 11 分現在、 70 センチの津波を観測しており ます。

A $70 \mathrm{~cm}$ tsunami was observed at 15:11 p.m.

第1波より第2波の方が大きくなっております。

The second wave is bigger than the first wave.

現在も引き潮になっておりますので、海岸付近に は、絶対に近づかないようにして下さい。There is now an ebb tide, so (please) do not approach the seaside.

繰り返します。

I will repeat it. (repetition of the above). . .

こちらは防災女川広報です。

This is the Disaster Prevention Onagawa Publicity Department.

(チャイム) (chime)

h. Kamaishi City, Iwate Prefecture (male, natural voice, sense of urgency)

サイレン、サイレン・..(sirens)

ただ今、岩手県沿岸に大津波警報が発表されました。

The Big Tsunami Warning has been issued for the coast of Iwate Prefecture. 
岩手県沿岸に大津波警報が発表されました。

The Big Tsunami Warning has been issued for the coast of Iwate Prefecture.

高いところで $3 \mathrm{~m}$ 以上の波が予想されます。

A tsunami of more than three meters is expected.

今すぐ海岸付近にいる方は、近くの高台か避難場所 に避難して下さい。

People at the seashore should (please) evacuate to a hill or an emergency evacuation site.

大津波警報が発表されました。

The Big Tsunami Warning has been issued.

高いところで $3 \mathrm{~m}$ 以上の波が予想されます。

A tsunami of more than three meters is expected.

直ちに近くの高台か避難所へ避難を指示します。

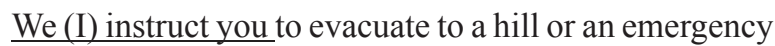
evacuation site.

サイレン、サイレン、サイレン、(sirens)

i. Kamaishi City Iwate Prefecture (male, natural voice, sense of urgency)

ただ今、岩手県沿岸に大津波警報が発表されまし た。

The Big Tsunami Warning has been issued for the coast of Iwate Prefecture.

高いところで $3 \mathrm{~m}$ 以上の津波が予想されます。

A tsunami of more than three meters is expected.

沿岸付近にいる方は、直ちに近くの高台か避難場所 に避難するよう指示します。

People at the seashore are instructed to evacuate to a hill or an emergency evacuation site.

サイレン (siren, repetition of the above)...

パトカーのサイレン、(

消防団の人の声 (natural voice of a person from the fire brigade)

高台にあがって下さい。津波が来ます、高台にあが って下さい。

Please go up the hill! The tsunami is coming! Please go up the hill!

Although not all of the messages are clear and short, the chief characteristics of these announcements are clear. First let us look at their tone and speed, which are usually studied under the subjects of prosody in linguistics. Because the intention of the Evacuation Instructions is to persuade local residents to evacuate immediately, the tone of voice used should convey urgency. The voices of most announcements (4a-e) are very slow, however, and show no sense of urgency: some announcements (4a-d) are pre-recorded, so a state of emergency is not obvious. The speed of other announcements $(4 \mathrm{f}-\mathrm{i})$ is comparatively fast. Although public announcements should be intelligible to elderly people and small children, in an emergency they must be spoken faster than usual. When there are many things to relate $(4 \mathrm{e}-\mathrm{i})$ to local residents, the announcer should talk faster, otherwise people might miss some important parts of the messages. In addition, (4d), (4e), and $(4 \mathrm{~g})$ began with chimes, which are used in ordinary situations in schools, airports, hospitals, and other public facilities before an announcement starts. The sound of chimes in the emergency warning announcements reduced their sense of urgency. In contrast, there were loud sounds of sirens in the recordings of (4f), (4h), and (4i) between announcements. These sirens make us feel that unusual events have occurred, so their use becomes more effective because they catch the listener's attention.

Next we have to look at the content and expressions of each announcement, which convey the intention of instruction in the framework of pragmatics. Unfortunately most of the content is the same as what the JMA usually transmits, as in (1), and what multi-media normally transmit to people over a broader area. For example, most of them said "The Big Tsunami Warning has been issued for the coast of Iwate Prefecture." This is the passive form of the verb and it suggests that the municipality did not issue the warning but is merely passing it along to listeners. The precautions and advice have the same contents as written in (1) JMA's Tsunami Warnings and precautions and advice. To take the intention of themunicipalityinstructionsintoaccount, theseannouncements do not need to give this kind of source information; rather, they have to make the local residents take evasive action. Examples (4h) and (4i), however, used the expression "We (I) instruct you to evacuate..." This expression shows where the instruction came from and who decided on the Evacuation Instruction.

Another point concerns the effort that the addressees need to make in order to understand these announcements. In pragmatics, when people need too much effort (energy) to understand an announcement, they do not pay attention or stop understanding. The announcement in (4e) repeated "The Big Tsunami Warning Number 3," but many people do not know what Warning Number 3 means. This places a great burden on the addressees to decipher the message's meaning. Other sentences in these announcements are too long and complicated, so they demand a great deal of effort on the part of the listener to understand. Arai (2011) cites the evacuation orders that flight attendants give to passengers in the case of an emergency landing and ditching as good examples of good announcements. They use a limited number of words (phrases), and are very clear and easy to understand.

Finally, it is a Japanese custom that even in an emergency people should use polite expressions in public or to strangers. Kudasai (please) was used in all announcements in (4). Even at the moment when the tsunami was engulfing the town, the announcements sounded very polite: "Please evacuate this area." In order to convey a sense of emergency, announcements should never use this kind of polite expressions for Evacuation Instructions. 


\section{Effective Evacuation Instructions}

In Section 4 most of the announcements that are supposed to convey Evacuation Instructions' intention in Japan are not effective enough from the viewpoint of linguistics and pragmatics, with one notable exception, which in fact saved lives.

According to Inoue (2011), Ooarai (which has a population of about 18,000) in Ibaragi Prefecture was struck by a 4-meter-high tsunami in the great earthquake on 11 March 2011, but there were no casualties in the town. Inoue suggests that the unusual announcements used by the municipality significantly helped the local residents. Below is a transcription of the recorded announcements.

(5) Ooaraimachi, Ibaraki Prefecture (male, natural voice, slowly but with sense of urgency)

サイレン、サイレン、・开イレン、

(sirens, many times and very loud)

緊急避難命令、緊急避難命令、

Emergency evacuation order! Emergency evacuation order!

大洗町・・50km??に大津波が発生しております。

At $50 \mathrm{~km}$ off ... Ooaraimachi ...The big tsunami occurred.

大至急、高台に避難して下さい。

(Please) evacuate to a hill immediately.

サイレン、サイレン・.. (sirens)

緊急避難命令、緊急避難命令、

Emergency evacuation Order! Emergency evacuation Order!

大洗町…50 km?に大津波が発生しております。

At $50 \mathrm{~km}$ off ... Ooaraimachi ... The big tsunami occurred.

大至急、高台に避難して下さい。

(Please) evacuate to a hill immediately.

The big difference is that the announcer used the words "Emergency evacuation order" that are not included in any official manuals or guidelines. Inoue suggests that one of the reasons for their success is the unusual voice messages broadcast by Mr. Kotani (the mayor of the town), Mr. Furukawa (the head of the fire department), and Mr. Masuda (a fireman). The messages are unusual, because they are all army-like commands, such as, "Emergency evacuation order!," "Evacuate immediately!" "Evacuate to the hill!" and "Don't go back to your home!" and so on (these are not in the recording above). According to the survey conducted by Inoue in Ooarai, many of the residents said that the un dusual army-like commands made them realize there was a state of emergency and it helped them to escape from the dangerous area immediately.

From the pragmatics perspective this new type of announcement had more cognitive effects and drew more attention from the residents. Cognitive effects are defined as a change of information in people's minds. The more cognitive effects people feel, the more people pay attention to the utterance (see Inoue (2012) on using "orders" for evacuation).

In addition to this fact, according to Inoue's survey, Mr. Kotani was also wary of the danger of crying wolf, so he advised his colleagues not to repeat the same expressions too often. The problem is a real one, for in many instance people thought the Tsunami Warning was not accurate because the tsunami in the Chili earthquake in the previous year failed to attain the predicted magnitude (Kanai et al. 2011). This "cry wolf" problem should be analyzed carefully from the perspective of linguistics in future research and planning.

\section{TV Tsunami Emergency Report}

In December 2012 an earthquake in the middle of the Richter scale struck the Tohoku area again. Soon after the Tsunami Warning was issued by the JMA, NHK (Nihon Houso Kyoukai, Japanese national broadcast company) switched its normal program to a Tsunami Emergency Report program. In the program anewsreadersaid "(Please) evacuate immediately! Remember the East Japan Tsunami Disaster!" very loudly with a sense of emergency and urgency. It was broadcast nationwide. After the East Japan Tsunami Disaster, in order to give more effective advice to the audience, the company trained its newsreaders. viii

Those people who had experienced the tsunami just a few years ago complained about the broadcasting. The announcements reminded them of recent tsunami experiences too vividly, according to the Asahi newspaper on 20 December 2012 in Headline: It reminded us the day. We run away.

As mentioned in Section 2, pragmatics emphasizes meanings that change in different contexts. The people who have experienced terrible tsunamis still remember the fear and sadness the events caused even now. But they try not to think about those emotions in order to recover from the shock. Consequently, "Remember East Japan Tsunami Disaster!" means, "Remember the fear and sadness!"

Another crucial mistake was the ignorance of the role the news media had in the disaster information transmission system as a whole. News media broadcast instructions that only municipalities can give to the local residents. The news media are not allowed to issue Evacuation Instructions or Advice, so this could be a violation of the law, strictly speaking.

In addition to that, only a few small tsunamis came in the December 2012 episode. When the next really big tsunami comes, the audience of the TV program might ignore the instructions. This is the "cry wolf" effect as mentioned in the previous section. This event, however, has paradoxically shown us the importance of each institution being aware of their roles and responsibility in effective disaster information transmission. 


\section{Conclusion}

In this study, with a focus on the Tsunami Warnings issued by the JMA and the Evacuation Instructions issued by municipalities, the present disaster information transmission system in Japan was examined from a perspective of pragmatics in linguistics.

From the viewpoint of pragmatics, in order to succeed in information transmission the intentions should be congruent with their linguistics expressions. Japanese legislation concerning disaster information transmission has been constructed in the ideal way. However, by examining the live recordings of outside speakers in the actual event of tsunami impacts, we found that the municipalities failed to convey their intentions to the local resident successfully. In addition, NHK, one of the media responsible for passing out unprocessed disaster information to the people, has changed the warning expressions in an undesirable way.

Some of the problems of disaster information transmission in Japan can be clarified by using linguistics theory to examine the language aspects of disaster information dissemination. Comparison of the effectiveness of different languages (such as Japanese versus English) in disaster information transmission will be the theme of our next study.

In 2012 the author set up a Disaster Prevention Language Study Group, which included six scholars of linguistics (from the fields of pragmatics, syntax, semantics, and translation), one marketing and advertising expert, and four meteorologists. We are now discussing what constitutes effective emergency communication in Japan and are trying to draw up guidelines for evacuation procedures from the perspective of the language used to motivate people to act quickly and reduce exposure to risk.

The head of the fire department of Ooarai, Mr. Furukawa said, "Once a disaster happens, the only way to evacuate people is through language," which convinced us that linguistics as a field of language study can contribute significantly to disaster prevention communication.

\section{Notes}

i The Tsunami Warnings issued by the Japan Meteorological Agency include big tsunami warnings, normal tsunami warnings, and tsunami advice. Evacuation Instructions and Evacuation Advice are issued by municipalities according to the level of the disaster risk.

i See JMA's Investigation of the Tsunami Alert Reports at http:// www.jma.go.jp/jma/press/1110/19a/tsunami_kentokai_1st.htm (in Japanese) and the JMA Website for Earthquake and Tsunami Disasters at http://www.jma.go.jp/jma/indexe.html (in English).

iii The author uses some ideas from relevance theory, one of the pragmatic theories. See Sperber and Wilson (1996) and Wilson and Sperber (2012) for the details about the theory. iv http://law.e-gov.go.jp/htmldata/S27/S27HO165.html.

v http://law.e-gov.go.jp/htmldata/S36/S36HO223.html.

vi See the Result of the 3/11 East Japan Earthquake Survey at the Kamaishi City website: http://www.city.kamaishi.iwate.jp/index. $\mathrm{cfm} / 6,19757,34, \mathrm{html}$ (in Japanese).

vii URLs of YouTube recordings http://www.youtube.com/watch?v= anHEC2Cmh5Q Kamaishi City, Iwate Prefecture http://www.you tube.com/watch? $v=$ YEbFsDs5Nh4 Ooaraimachi, Ibaraki Prefecture http://www.youtube.com/watch?v=ZuAhx_ZYcvE Shiogama Bay, Miyagi Prefecture http://www.youtube.com/watch?v=TK1SsQ36P4 Shiogama City, Iwate Prefecture and Aomori Prefecture https:// www.youtube.com/watch?v=NgobVz0KB 4 Miyako City Hall, Iwate Prefecture http://www.youtube.com/watch?v=pC52MVqsEFw Oofunato Bay, Iwate Prefecture https://www.youtube.com/watch?v= $629 \mathrm{em} 0 \mathrm{mPpUY}$ Kamaishi City Iwate Prefecture https://www.you tube.com/watch? $v=e 550 x N q p E L o$ Onagawa Tow, Miyagi Prefecture

viii See the NHK emergency earthquake broadcast training on YouTube: http://www.youtube.com/watch? $=$ oBFJF36BEak.

\section{References}

Arai, K. 2011. Emergency Communication - How to Convey Evacuation Directives. Keieironshu No. 78: 27-38. The Faculty of Business Administration, Toyo University (in Japanese).

Arai, K. 2013a. The Communication of Disaster Prevention and Relevance - How to Transmit Tsunami Warnings Effectively. Keieironshu No. 81: 91-105. The Faculty of Business Administration, Toyo University (in Japanese).

Arai, K. 2013b. The Disaster Information Transmission Problems from the Pragmatics Perspectives - An Example of Applied Relevance Theory. Goyoron Kenkyu No. 15. Japan Pragmatics Association (forthcoming, in Japanese).

Inoue, H. 2011. Why Did Oaarai-Machi Cry “Evacuate!"? - The Report on the Expressions Used by the Disaster Radio at the Time of the East Japan Earthquake and Tsunami Disaster. Broadcast Study and Survey, NHK Culture and Broadcast Institute, 2011 (September): 33-53 (in Japanese).

Inoue, H. 2012. Can We Use "Imperatives" in the Evacuation Instructions? - From the Viewpoint of the Effective Expressions for the Listeners. Broadcast Study and Survey, NHK Culture and Broadcast Institute, 2012 (November): 2-15 (in Japanese).

JMA (Japan Meteorological Agency). 2011. The Study Group on the Tsunami Warnings Reports. http://www.seisvol.kishou.go.jp/eq/ tsunami_kaizen_benkyokai/index.html (in Japanese).

Kanai. M., and T. Katada. 2011. The Discussion on the Social Correspondence for Inducing Residents' Evacuation from Tsunami Attacks - From the Actual Evacuation Conditions at Chile Earthquake in 2010. Disaster Information, Japan Society for Disaster Information Studies: No. 9: 103-113 (in Japanese).

Kanai, M., K. Shima, T. Kojima, and T. Katada. 2011. Meta-Message Effects for Flood Evacuation Advice Information. Disaster Information No. 9, Japan Society for Disaster Information Studies: 161-171 (in Japanese).

Sperber, D., and D. Wilson. 1996. Relevance - Communication and Cognition, second edition. Oxford: Blackwell Publishers.

Wilson, D., and D. Sperber. 2012. Meaning and Relevance. Cambridge: Cambridge University Press.

Yamori, K. 2009. The Double Bind on Disaster Information. Disaster Information No.7, Japan Society for Disaster Information Studies: 28-33 (in Japanese).

Open Access This article is distributed under the terms of the Creative Commons Attribution License which permits any use, distribution, and reproduction in any medium, provided the original author(s) and source are credited. 